Journal of Applied Pharmaceutical Science Vol. 3 (09), pp. 057-059, September, 2013

Available online at http://www.japsonline.com

DOI: $10.7324 / \mathrm{JAPS} .2013 .3910$

ISSN 2231-3354 (cc) BY-NC-SA

\title{
Resistance Pattern acquired by nosocomial pathogens: a plasmid profilestudy
}

\author{
Smaranika Pattnaik ${ }^{1}$, Monalisa Pradhan ${ }^{1}$ and Manoj Narayani ${ }^{2}$ \\ ${ }^{1}$ Laboratory of Medical Microbiology, School of Life Sciences, Sambalpur University, Jyoti Vihar, Burla 768019, Odisha, India; 2, Deptt. of Life Sciences, \\ National Institute of Technology, Rourkela, Odisha, India.
}

\begin{tabular}{l}
\hline ARTICLE INFO \\
\hline Article history: \\
Received on: $13 / 08 / 2013$ \\
Revised on: $01 / 09 / 2013$ \\
Accepted on: $20 / 09 / 2013$ \\
Available online: $30 / 09 / 2013$ \\
\hline
\end{tabular}

Key words:

Nosocomials, drug resistance, plasmid.

\begin{abstract}
Nosocomial (Hospital acquired) bacterial strains were isolated from the premises of V.S.S. Medical College and Hospital, Burla, Odisha. The strains were preliminarily characterized by using "Routine diagnostic methods" and were identified as Pseudomonas sp., Klebsiella sp., Bacillus sp. respectively. The resistance nature of all the nosocomial strainswere clearly evident from the "Sensitivity testing" by following Kirby-Bauer method. A plasmid profile study revealed that all the isolated and identified strains were harboured with plasmids. Provisionally a concluding statement was given for the possible role of plasmids in drug resistance acquired by nosocomial bacterial strains.
\end{abstract}

\section{INTRODUCTION}

A hospital-acquired infection, also known as a HAI or in medical literature as a nosocomial infection, is an infection whose development is favoured by a hospital environment, such as one acquired by a patient during a hospital visit or one developing among hospital staff. Such infections include fungal and bacterial infections and are aggravated by the reduced resistance of individual patients.

Bacteria recognized as nosocomial pathogens generally fall into three categories: those that grow slowly, those that are fastidious in their nutritional or atmospheric requirements and those that resemble commensals (Fraser, 1981). Because some of these organisms are fastidious, they have not always been readily cultured and identified. Other species have not been fully appreciated as nosocomial pathogens because of taxonomic uncertainties (Mayer and Zinner, 1985). Gram positive bacteria are the commonest cause of nosocomial infections with Staphylococcus aureus being the predominant pathogen (Inweregbu et al., 2005). Therefore there is a need for a solution to

\footnotetext{
* Corresponding Author

Dr (Mrs) Smaranika Pattnaik

Laboratory of Medical Microbiology School of Life Sciences

Sambalpur University Jyoti Vihar, Burla 768019, Odisha
}

combat with these nosocomial members. Keeping this quandary in mind, this study is a small piece of research, an attempt to nuke out the nature of resistance acquired by some of isolated bacteria strains from a hospital Environment. V.S.S. Medical College, Burla Odisha, which is regarded as a Primary Health Care Centre of Western Odisha and neighbouring states. The present pursuit had taken this Hospital environment to study about the nature of resistance acquired by the nosocomials.

\section{MATERIALS AND METHODS}

\section{Media taken for the study}

Nutrient agar and broth were taken for the study was prepared according to HI-Media company instructions.

\section{Bacterial strains taken for the study}

The bacterial strains were obtained from Deptt. of Microbiology, V.S. S. Medical College in the form of Research material. The strains were Pseudomonas sp., Klebsiella $s p$. and Bacillus sp. respectively. The strains were subjected to further identification in the laboratory of Medical Microbiology, School of Life Sciences, Sambalpur University by following routine diagnostic procedures. 
The bacterial cultures were subjected to streaking on Nutrient agar plates to get isolated colonies. Further isolated colonies were studied for morphology i.e. colour, odour, elevation, margin etc. The results are depicted in Table \#1. Further the colonies were subjected to Gram staining as well as live cells staining to differentiate Gram positive and Gram negative as well as motile and non motile respectively.

\section{Study for sensitivity \\ Antibiotics taken for the study}

The Antibiotics taken for the study were Penicillin (1 $\mathrm{mg} / \mathrm{ml}$ ), Streptomycin (37 mg/ml), Tetracycline (1 $\mathrm{mg} / \mathrm{ml})$, Gentamicin (40 mg/ml), Levofloxacin (1 mg/ml), Ciprofloxacin (1 $\mathrm{mg} / \mathrm{ml}$ ) and Amoxillin (1 $\mathrm{mg} / \mathrm{ml})$. The drugs were procured commercially from local Medical stores.

\section{Sensitivity test}

\section{Disc diffusion method}

The procured antibiotics were subjected to sensitivity test by following Kirby and Bayer method (1968). The Antibiotics were dissolved in sterile distilled water maintaining concentration as mentioned previously. The Antibiotic solution impregnated $(4 \mu 1 /$ disc) filter paper discs were put onto seeded bacterial culture Nutrient agar plates. A control plate was included for a comparison study. The plates were incubated at $37^{\circ} \mathrm{C}$ for a period of 14 to $18 \mathrm{hrs}$. The clear zone around each disc was measured and referred as sensitive, very sensitive, moderately sensitive or resistant by referring Kirby Bayer chart.

\section{Tube dilution method}

Tube Dilution method (Pattnaik et al., 2010) was followed to determine the minimum inhibitory concentration of drugs. The drugs were taken in a range starting from lower concentration, $1 \mu \mathrm{g} / \mathrm{ml}(\mathrm{v} / \mathrm{v})$ to higher concentration $50 \mu \mathrm{g} / \mathrm{ml}$ $(\mathrm{v} / \mathrm{v})$ in bacterial culture seeded broths. After incubation for a period of $48 \mathrm{hrs}$, the broths were observed with growth (Resistant) or no growth (Sensitive) of bacterial strains.

\section{Plasmid profile study of bacterial strains}

The three bacterial strains namely Pseudomonas, Klebsiella and Bacillus were subjected to isolation for plasmids (if any) by following method of Sambook and Russel ( 2001) in the $M$ and $M$ laboratory, National Institute of Technology (NIT), Rourkela, Odisha.

\section{RESULTS AND DISCUSSION}

\section{Identification of nosocomial bacterial strains}

The bacterial strains (NCB1, NCB 2 and NCB3) grown on respective nutrient agar plates were observed to be members of three different genera namely Pseudomonas sp., Klebsiella sp. and Bacillus sp. which was evident from their colony characteristics (Table \#1). Additionally the light microscopic study substantiated the observation (Table \#2).
Table. 1: Colony characteristics: NCB: Nosocomial bacteria \#1,2, and 3 respectively.

\begin{tabular}{cccc}
\hline Parameters for identification & NCB1 & NCB2 & NCB3 \\
\hline Elevation & Flat & Raised & Convex \\
Margin & Entire & Entire & Wavy \\
Optical density & Translucent & Opaque & Opaque \\
Colour & Green & Whitish & Wheatish \\
Colony forms & Irregular & Circular & Irregular \\
\hline
\end{tabular}

Table. 2: Microscopical charachteristics.

\begin{tabular}{|c|c|c|c|}
\hline $\begin{array}{c}\text { Parameters for } \\
\text { identification }\end{array}$ & NCB1 & NCB2 & NCB3 \\
\hline Shape & Swollen Rods & Varied Rods & Long rods \\
\hline $\begin{array}{l}\text { Response to Gram } \\
\text { stain }\end{array}$ & Gram negative & Gram negative & Gram positive \\
\hline Motility & Motile & Non motile & Motile \\
\hline
\end{tabular}

\section{Study for sensitivity \\ Disc diffusion method}

From the results depicted in Table \# 3, it was observed that the three nosocomial bacterial strains were resistant to the all the antibiotics having a minimized zone of inhibition or no zones of inhibition either. But the Bacillus stain was observed to be sensitive towards Levofloxacin and intermediately sensitive to Streptomycin respectively. Based upon this result it may be inferred that all the test strains were resistant to most of drugs.

Table. 3: depicting the results obtained from Test for sensitivity (Disc diffusion) of antibacterial drugs depicting zones of inhibition in diameter (mm), no zones of inhibition: R, S: Sensitive, IS: Intermediately sensitive.

\begin{tabular}{lccc}
\hline \multirow{2}{*}{$\begin{array}{c}\text { Names of } \\
\text { Antibiotics }\end{array}$} & NCB1 & NCB2 & NCB3 \\
\cline { 2 - 4 } & Pseudomonas sp & Klebsiella sp & Bacillus sp. \\
\hline Amoxicillin & $12(\mathrm{R})$ & $10(\mathrm{R})$ & $12(\mathrm{R})$ \\
Ciprofloxacin & $8(\mathrm{R})$ & $7(\mathrm{R})$ & $11(\mathrm{R})$ \\
Gentamycin & $6(\mathrm{R})$ & $6(\mathrm{R})$ & $\mathrm{R}$ \\
Levofloxacin & $15(\mathrm{R})$ & $12(\mathrm{R})$ & $25(\mathrm{~S})$ \\
Penicillin-G & $8(\mathrm{R})$ & $10(\mathrm{R})$ & $\mathrm{R}$ \\
Streptomycin & $10(\mathrm{R})$ & $9(\mathrm{R})$ & $18(\mathrm{IS})$ \\
Tetracycline & $\mathrm{R}$ & $10(\mathrm{R})$ & $\mathrm{R}$ \\
\hline
\end{tabular}

\section{Tube dilution method}

In an experiment regarding the sensitivity test for nosocomial bacterial strains towards the antibiotics namely, Amoxicillin, Ciprofloxacin, Gentamycin, Levofloxacin, PenicillinG, Streptomycin and Tetracycline, it was found that the bacterial strains were resistant upto $\leq 50 \mu \mathrm{g} / \mathrm{ml}(\mathrm{v} / \mathrm{v})$. From this observation it may be anecdotal about the resistance nature of nosocomials.

\section{Plasmid profile study of bacterial strains}

The Figure \# 1 depicts the plasmid profile of the nosocomial strains. From the Agarose gel electrophoresis of plasmid DNA, it was observed that the Klebsiella sp. had maximum bands of plasmid DNA, while in Pseudomonas showed two number of plasmid DNA bands. In contrast, the Bacillus strain was having a diffused band of plasmid DNA. Plasmid profile analysis (PP) is a method of determining a number and size of plasmids in bacterial isolates (Selimovic et al, 2008). This observation could explain the drug resistance among nosocomials could be due to presence of resistance genes in their respective plasmids (Patwardhan et al, 2009). 


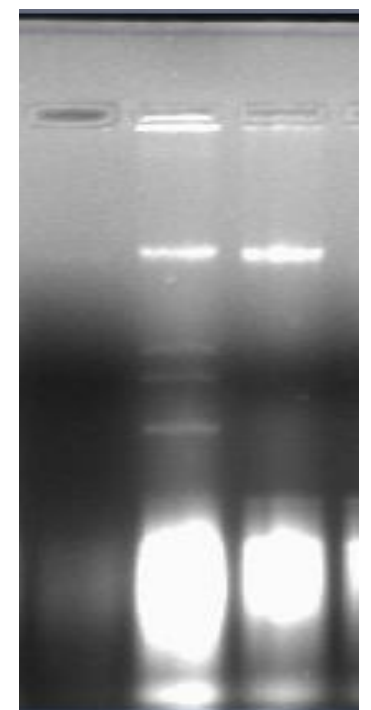

Fig. 1: depicting plasmid bands in the agarose gel. Lanes A: Bacillus with a faint plasmid band .

B: Klebsiella with 5 plasmid bands.

C: Pseudomonas with 2 plasmid bands.

Arrows are indicative of plasmid bands.

\section{CONCLUSION}

From this piece of research work it may be concluded that the nosocomial bacterial strains isolated from Hospital environment were rigid towards a number of antibacterial drugs. Further it was observed that the strains were endowed with plasmids. And moreover, it was observed Klebsiella sp was found to be harbored with more number of bands.

This is pertinent to mention here that, plasmids are notorious for horizontal gene transfer among bacterial strains. The nosocomial bacterial strains are always in course of horizontal gene transfer (hGT) conferring the strains drug resistant (Dzidic and Bedekovic, 2003). This study may be in juvenile stage, but may pave a way for investigating more about the mechanism responsible for hGT among nosocomial bacterial strains isolated and identified from a regional health hub.

\section{ACKNOWLEDGEMENT}

The authors are truly thankful to $\mathrm{M}$ and $\mathrm{M}$ lab, National Institute of Technology (NIT), Rourkela, Odisha for providing necessary facilities to carry out the plasmid profile study.

\section{REFERENCES}

Fraser D.W., Bacteria newly recognised as nosocomial pathogens, Am J. Med, 1981; 70 (2): 432-8.

Mayer K.H. and Zinner, S.H. Bacterial pathogens of increasing significance in hospital acquired infections, Rev. Inf Dis. 19851 (Suppl 3): S 371-9.

Inweregbu K., Dave J. and Pittard A. Continuing Education in Anaesthesia, Critical Care and Pain 2005; 5 (1): 14-17.

Bauer AW, Kirby WM, Sherris JC, Turck M. Antibiotic susceptibility testing by a standardized single disk method. Am J Clin Pathol. 1966, 45 (4):493-496

Pattnaik S, Padhan DK and Jana GK Evaluation of Cinnamon Oil, Peppermint Oil, Cardamom Oil and Orange Oil as Antimicrobial Agents, Journal of Pharmacy Research, 2010, 3 (2):414-416.

Sambrook J. and Russel, DW. 2001. Plasmids and their usefulness in molecular cloning In: Molecular cloning : a laboratory Mannual, CSHL, New York.

Selimovic BM, Babic T, Kocic B, Stojanovic P, Ristic L and Dinic M, Plasmid profile analysis of Salmonella enterica serotype enteritidis, Acta Medica Medianae, 2008, 47: 54-57.

Patwardhan RB, Dhakephalkar PK, Dhakephalkar KB, Niphadkar and Chopade BA. A study on nosocomial pathogens in ICU with special reference to multiresistant Acinetobacter baumannii harbouring multiple plasmids. Indian J Med Res, 2008; 128: 178-187.

Dzic S. and bedekovic V., Horizontal gene transfer-emerging multidrug resistance in hospital bacteria, Acta Pharmalogica Sinica, 2003, 24 (6): 519-526.

\section{How to cite this article:}

Smaranika Pattnaik, Monalisa Pradhan and Manoj Narayani., Resistance Pattern acquired by nosocomial pathogens: a plasmid profile study. J App Pharm Sci, 2013; 3 (09): 057-059. 